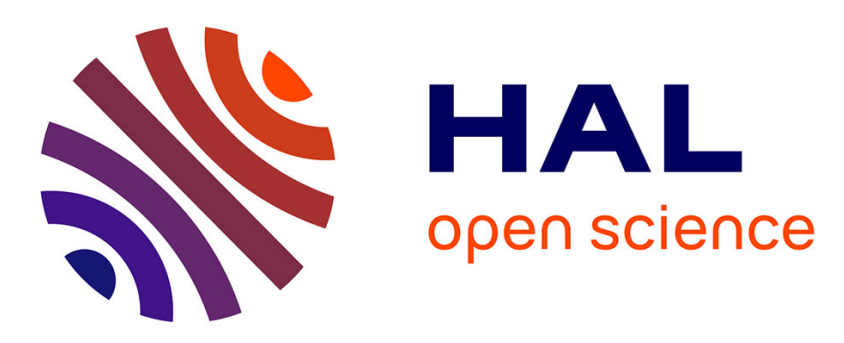

\title{
Reliability quantification and gait loading asymmetry assessment with wearable insoles in transfemoral amputee people at different speeds
}

Isabelle Loiret, Coralie Villa, Boris Dauriac, Xavier Bonnet, François Lavaste, Noël Martinet, Jean Paysant, Hélène Pillet

\section{To cite this version:}

Isabelle Loiret, Coralie Villa, Boris Dauriac, Xavier Bonnet, François Lavaste, et al.. Reliability quantification and gait loading asymmetry assessment with wearable insoles in transfemoral amputee people at different speeds. Clinical Neurophysiology, 2016, 46 (4-5), pp.267. 10.1016/j.neucli.2016.09.074 . hal-02865990

\section{HAL Id: hal-02865990 \\ https://hal.science/hal-02865990}

Submitted on 12 Jun 2020

HAL is a multi-disciplinary open access archive for the deposit and dissemination of scientific research documents, whether they are published or not. The documents may come from teaching and research institutions in France or abroad, or from public or private research centers.
L'archive ouverte pluridisciplinaire $\mathbf{H A L}$, est destinée au dépôt et à la diffusion de documents scientifiques de niveau recherche, publiés ou non, émanant des établissements d'enseignement et de recherche français ou étrangers, des laboratoires publics ou privés. 
Déclaration de liens d'intérêts Les auteurs déclarent ne pas avoir de liens d'intérêts.

\section{Reliability quantification and gait loading asymmetry assessment with wearable insoles in transfemoral amputee people at different speeds}

Isabelle Loiret ${ }^{1, *}$, Coralie Villa ${ }^{2,3}$, Boris Dauriac ${ }^{2}$, Xavier Bonnet $^{2}$, François Lavaste ${ }^{2,3}$, Noel Martinet ${ }^{1}$, Jean Paysant ${ }^{1}$, Hélène Pillet ${ }^{2}$

1 Institut de médecine physique et de réadaptation, UGECAM Nord-est, Nancy, France

${ }^{2}$ Arts et métiers ParisTech, institut de biomécanique humaine Georges-Charpak, Paris, France

${ }^{3}$ Institution nationale des invalides, CERAH, Créteil, France

* Corresponding author.

E-mail address: isabelle.loiret@ugecamne.fr (I. Loiret)

Introduction Amputee people have gait defaults, as for example loading asymmetry, which increase with daily living situations. Replication of realistic daily living environment in a motion analysis laboratory (MAL) is difficult. Wearable pressure insoles, by providing normal ground reaction force (NGrF), can be used to quantify loading gait asymmetry in real life conditions. This asymmetry, considered as an indicator of the quality of the gait, is useful for physicians to monitor the rehabilitation progress or the prosthetic fitting suitability. The study aimed at quantifying the reliability of NGrF measurement and assessing the gait asymmetry of transfemoral amputee people with Pedoped ${ }^{\circledR}$ insoles against force plates. Walking speed effect was also evaluated on gait asymmetry for transfemoral amputee people (TFP).

Material and methods In a MAL, five active TFP walked at three self-selected speeds on level ground wearing Pedoped ${ }^{\circledR}$ insoles. Reliability was assessed by comparing NGrF obtained from both systems with Bland-Altman plots, normalized RMSE (NRMSE) and correlation coefficient. Gait loading asymmetry was computed by Absolute Symmetry Index in loading at the three self-selected speeds with insoles.

Results The mean NRMSE of NGrF was $7.2 \%( \pm 2.8 \%)$ and $9.8 \%$ $( \pm 3.5 \%)$; and coefficient correlation was 0.91 and 0.95 for the prosthetic side and the intact side respectively. Loading asymmetry increased significantly with walking speed for each specific variable of NGrF.

Discussion-conclusion After overcoming the calibration problem in amputee population, Pedoped ${ }^{\circledR}$ insoles could be easily used for gait asymmetry follow-up during rehabilitation.

Keywords Insoles; Locomotion; Amputation; Rehabilitation

Disclosure of interest The authors declare that they have no competing interest.

\author{
Whiplash trauma to the vestibular \\ system: What effect does whiplash \\ have on the ear? \\ Neil Longridge ${ }^{1,2, *}$, Art Mallinson ${ }^{1,2}$ \\ ${ }^{1}$ Neuro-otology Unit, Vancouver General Hospital, Vancouver, \\ Canada \\ 2 Division of Otolaryngology, Department of Surgery, Faculty of \\ Medicine; University of British Columbia, Canada \\ * Corresponding author. \\ E-mail address: nslongridge@hotmail.com (N. Longridge)
}

Introduction Dizziness after traumatic acceleration/deceleration injury is well-known and the complaints voiced by these patients are similar to those of many non-trauma patients referred with vestibular sounding complaints. Patients often deny spinning but voice "non-traditional" complaints of imbalance, subtle boat like feelings and nausea. These complaints may arise because of otolithic damage from the trauma. It is traditionally thought that most vestibular pathology is unilateral and our concern is that trauma patients may have suffered bilateral damage due to the mechanism of the injury. We felt the need to document this. Pathology in these patients is important to define, as bilateral pathology is more of a challenge to compensate for. Material and methods We assess patients with computerized dynamic posturography in our tertiary care diagnostic unit, but we also carry out vestibular-evoked myogenic potential (VEMP) assessment which can document and quantify otolithic pathology. Posturography, OVEMP and CVEMP results were compared in 25 whiplash trauma patients with an age and sex matched group of non-trauma patients with spontaneous vestibular disease.

Results We examined both groups of patients with respect to CVEMP and OVEMP abnormalities. Posturography results were not different between the two groups but there was a statistically higher OVEMP abnormality rate in the trauma group when compared to the vestibular non-trauma patients. The meaning of this will be discussed.

Discussion-conclusion We will be discussing the findings in our two groups of patients. It is important to document the pathology in these patients as being vestibular, as immediate activation with "goal directed" activities in the patient with vestibular pathology is extremely important. Our concern is patients may be diagnosed with "post concussion syndrome"; the treatment for this is complete rest.

Keywords Whiplash; Diagnostics; Otoliths

Disclosure of interest The authors declare that they have no competing interest.

\section{Dépersonnalisation et déréalisation dans les troubles de l'équilibre d'origine vestibulaire}

Christophe Lopez ${ }^{1, *}$, Maya Elziere ${ }^{2}$

${ }^{1}$ CNRS, LNIA, FR3C, Aix-Marseille université, Marseille, France ${ }^{2}$ Centre des vertiges, hôpital européen, Marseille, France

* Auteur correspondant.

Adresse e-mail : christophe.lopez@univ-amu.fr (C. Lopez)

Introduction Les atteintes du système vestibulaire dégradent la posture, la locomotion et la stabilisation du regard. Certains patients avec une atteinte vestibulaire rapportent également des modifications de la perception de leur soi, ou des sensations d'étrangeté et d'irréalité de leur corps et leur environnement. Ces symptômes se rapprochent des troubles de dépersonnalisation et déréalisation (DD). Parce que ces symptômes sont encore peu explorés, cette étude mesure leur nature et leur prévalence chez des patients souffrant de troubles vestibulaires centraux ou périphériques et chez des sujets contrôles.

Matériel et méthodes Soixante patients consultant pour des troubles de l'équilibre ont complété des questionnaires mesurant la DD (Cambridge Depersonalization Scale), l'anxiété et la dépression (HAD Scale) après un examen otoneurologique. Un groupe contrôle incluait 60 volontaires sains appariés en âge et en sexe.

Résultats Nos données préliminaires indiquent que les patients vestibulaires rapportent fréquemment « Je me sens étrange, comme si je n'étais pas réel ou coupé du monde » (c.-à-d. dépersonnalisation : $60 \%$ ), «L'environnement autour de moi paraît détaché 